\title{
Freezing Stress Influences Emergence of Germinated Perennial Grass Seeds
}

\author{
Chad S. Boyd ${ }^{1}$ and Jarrod A. Lemos ${ }^{2}$ \\ Authors are ${ }^{1}$ Research Scientist and ${ }^{2}$ Research Technician, USDA-ARS Eastern Oregon Agricultural Research Center, Burns, OR 97720 , USA.
}

\begin{abstract}
In sagebrush rangelands perennial bunchgrasses are typically seeded in fall and a high proportion of planted seeds germinate prior to winter onset but fail to emerge in spring. Our objectives were to evaluate freezing tolerance of germinated but nonemergent bluebunch wheatgrass seeds under laboratory conditions. We used data from a 2 -yr pilot study to determine overwinter freezing temperature and duration for soils in southeastern Oregon. We then conducted two experiments to assess freezing tolerance. In experiment 1, bluebunch wheatgrass seeds were planted in control pots and compared to seeds planted at early, mid, or late postgermination stages. Pots from each treatment were placed in a grow room maintained at $12 \mathrm{~h} 40 \mathrm{~min}$ light/11 h 20 min dark photoperiod, with a constant temperature of $22^{\circ} \mathrm{C}$ for $30 \mathrm{~d}$ either immediately or following a 30 -d freeze. In experiment 2, germinated bluebunch wheatgrass seeds were planted in pots that were left nonfrozen or were frozen for a

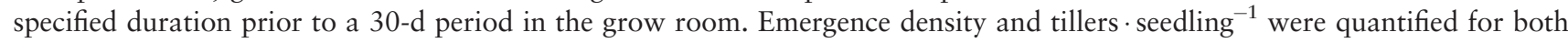
experiments. The number of days per year for freezing soil conditions in the pilot study ranged yearly from 25 to 51 ; maximum duration of continuous freezing was 16.5 and $11.2 \mathrm{~d}$. Freezing reduced or eliminated seedling emergence at all postgermination stages $(P<0.001)$ and tiller density was reduced by at least $50 \%(P<0.001)$. Maximum reduction in seedling density $(P<0.001)$ was realized within $4 \mathrm{~d}$ of initiation of freezing and tillers · seedling ${ }^{-1}$ were reduced $30-70 \%$ with $>6 \mathrm{~d}$ of freezing $(P=0.001)$. Our data indicate that freezing-associated mortality of germinated but nonemergent bluebunch wheatgrass seedlings can be extremely high and suggest that management practices to reduce prewinter germination of seeds could improve subsequent emergence and seeding success.
\end{abstract}

Key Words: bluebunch wheatgrass, emergence, restoration, sagebrush steppe, seedling mortality

\section{INTRODUCTION}

The ongoing invasion of western US sagebrush plant communities by nonnative annual grasses represents one of the largest known biological invasions of terrestrial systems (D'Antonio and Vitousek 1992; Chambers et al. 2007). Research clearly indicates that maintenance of perennial grasses is key to reducing the extent of annual invasion (Whisenant 1990; Crawford et al. 2004). Restoring the perennial grass component on sagebrush rangeland has proven exceedingly difficult, particularly at low elevations and with native species (Hull 1974; Richards et al. 1998; Mosley et al. 1999; Lysne and Pellant 2004). In fact, some estimates suggest that failure rates may approach $90 \%$, but more exact numbers are difficult to obtain because of underreporting of failed seedings (James and Svejcar 2010; Hardegree et al. 2011). Efforts to restore perennial grasses are set within a backdrop of extreme environmental variability over both space and time (Boyd and Svejcar 2009); however, restoration practices are often applied in a uniform manner across landscapes and between years. For example, a typical postfire restoration in the sagebrush steppe involves drill seeding of perennial grasses during fall (usually October or November). Data on timing of germination of fall-

\footnotetext{
The Eastern Oregon Agricultural Research Center is jointly operated by the USDA-ARS and the Oregon State University Agricultural Experiment Station. USDA is an equal opportunity provider and employer.

Correspondence: Chad Boyd, USDA-ARS Eastern Oregon Agricultural Research Center, 67826-A Hwy 205, Burns, OR 97720, USA. Email: chad.boyd@oregonstate.edu
}

Manuscript received 20 September 2012; manuscript accepted 5 January 2013.

(c) 2013 The Society for Range Management planted perennial grass seeds in the sagebrush steppe suggests that most of the seeds that will germinate do so prior to winter onset. For example, Boyd and James (in press) found that up to $80 \%$ of fall-planted bluebunch wheatgrass (Pseudoroegneria spicata [Pursh] A. Love) seeds germinated prior to winter. These data further suggest that emergence of fall-germinated seeds occurs the following spring, and that emergence is the most limiting demographic stage. Thus, germinated seeds must endure environmental extremes associated with overwinter freezing soils prior to emerging in the spring, perhaps at least partially accounting for exceedingly low emergence rates of $10-15 \%$ of germinated seeds (James et al. 2011; Boyd and James in press).

Previous work regarding the specific impact of freezing temperatures on subsequent emergence of germinated perennial grass seeds is extremely limited. Laude (1956) found that emergence of perennial grass seeds was decreased over $90 \%$ after a 20-h exposure to freezing soil conditions, 2-3 d following planting. However, subsequent research to refine knowledge of the relationship between frozen soils and seedling demography of perennial grasses has not been forthcoming. Our objectives were 1) to determine the influence of freezing on emergence and vigor of germinated bluebunch wheatgrass seedlings, 2) to differentiate this impact relative to postgermination developmental status at time of freezing, and 3) to determine the impact of freeze duration on germinated bluebunch wheatgrass seeds with respect to emergence and postemergence growth patterns. We hypothesized that 1) germinated seeds exposed to freezing would have decreased seedling emergence and subsequent vigor relative to germinated but nonfrozen seeds, 2) the degree to which seedling emergence 
and vigor is impaired would increase with advancing postgermination developmental stage, and 3) freeze effects on seedling emergence and performance would be independent of duration of freezing.

\section{METHODS}

\section{Experimental Design}

Design for experiment 1 was a complete randomized block with four replications. Factorial treatments included two levels of freezing treatment and five developmental classes. For experiment 2 we used a complete randomized block design with four replications. Treatments included a nonfrozen control and five levels of postgermination freeze duration. In both experiments we utilized an indoor grow room maintained at $12 \mathrm{~h} 40 \mathrm{~min}$ light $/ 11 \mathrm{~h} 20 \mathrm{~min}$ dark photoperiod, at a constant temperature of $22^{\circ} \mathrm{C}\left( \pm 3^{\circ} \mathrm{C}\right)$; LED lights (Sunshine Systems, LLC, Wheeling, IL) were used to maintain photoperiod.

\section{Procedures for Pilot Study}

We characterized field freezing temperatures/durations by instrumenting plots in a Wyoming big sagebrush plant community at the Northern Great Basin Experimental Range (approximately $50 \mathrm{~km}$ west of Burns, OR) for NovemberFebruary of 2008-2009 and 2009-2010 with Gro-Point thermistors (Environmental Sensors Inc., Sidney, British Columbia, Canada) buried at $1-2-\mathrm{cm}$ depth and programmed to record hourly temperatures (Boyd and James in press). We then determined average freezing temperature within year for freezing periods $\geq 24 \mathrm{~h}$, and calculated the duration of all freezing events. To determine a realistic duration of freezing for experiment 2, we used these data to calculate the maximum number of consecutive freezing days in each year. Corollary data for air temperature were collected at an existing nearby $(<1 \mathrm{~km})$ weather station.

\section{Procedures for Experiment 1}

We defined the following developmental classes: 1 ) radicle $\leq 2$ $\mathrm{mm}, 2$ ) radicle $>2 \mathrm{~mm}$ without coleoptile, 3) coleoptile present, 4) germinated in situ, and 5) nongerminated. For postgermination classes (classes 1-3) approximately 5000 Anatone bluebunch wheatgrass seeds (Lot LHS1D3-445-1; L\&H Seeds, Inc.; Connell, WA) were pregerminated by placing them on sections of moist blotter paper within $20 \times 30 \mathrm{~cm}$ metal pans, covered with Plexiglas and placed in a seed germination chamber (Hoffman Manufacturing, Inc., Albany, OR) at constant temperature and photoperiod. Pans were watered as needed and on day nine, 20 seeds of each postgermination class, plus nongerminated seeds were planted in 20-cm-diameter pots containing a silt loam soil. Two pots per developmental class were planted for each replication (i.e., 10 pots per replication). Seeds germinated in situ were planted, as above, $5 \mathrm{~d}$ prior to other seeds, watered (see below), and allowed to reach early postgermination stages by study initiation. To quantify in situ postgermination stage at $5 \mathrm{~d}$ postplanting, we seeded and maintained four pots as per those in the study, harvested seeds after $5 \mathrm{~d}$, and quantified postgermination developmental stage (based on radicle length and coleoptile presence/absence) of these seeds. The in situ treatment allowed us to further evaluate experimental error induced by seed germination and planting procedures. Soils within pots were hydrated to a water content of $15 \%$ by weight immediately prior to planting. Following planting, one pot (per replication) of each of the five developmental classes was placed in a random position within a laboratory freezer, and remaining pots were placed in random positions within blocks on tables in the indoor grow room for $30 \mathrm{~d}$. Based on the number of freezing days per year in the pilot study, we chose a freezing duration of 30 days. Freezer temperature was set at $-8.9^{\circ} \mathrm{C}$ for the first $10 \mathrm{~d},-4.5^{\circ} \mathrm{C}$ for the second $10 \mathrm{~d}$, and $-0.1^{\circ} \mathrm{C}$ for the remaining $10 \mathrm{~d}$ to mimic the range of freezing temperatures encountered in the pilot study. Freezer temperature was maintained with the use of a digitally controlled thermostat. To quantify rate of temperature decline, we instrumented four nonplanted pots with thermistors (as above) buried at $1 \mathrm{~cm}$ depth and recorded temperatures by minute for $2 \mathrm{~d}$ and averaged data across thermistors. Pots in the indoor grow room were watered (to $15 \%$ water content) at approximately 2 -d intervals to maintain initial moisture content. Because nonfrozen pots were in the indoor grow room prior to frozen pots, we used nonplanted dummy pots filled with soil to maintain a constant number of pots within each block. Frozen pots were removed from the freezer after 30 $\mathrm{d}$ and placed in a random location within blocks on tables in the indoor grow room. Seedling density was counted daily for each pot, and after the pots spent $30 \mathrm{~d}$ in the indoor growth room we conducted a final seedling density count, and counted the number of tillers per seedling.

\section{Procedures for Experiment 2}

Approximately 5000 Anatone bluebunch wheatgrass seeds were germinated in the lab as per experiment 1 . Pans were watered as needed and on day nine, 20 seeds per treatment replication were planted in 20 -cm-diameter pots containing a silt loam soil. Only seeds with radicles $\geq 2 \mathrm{~mm}$ (but prior to coleoptile emergence) were selected for planting. Soils within pots were watered as per experiment 1. Following planting, 20 pots were placed in a laboratory freezer maintained at $-7.5^{\circ} \mathrm{C}$, and the remaining 4 pots were placed in random locations on tables within blocks in the indoor grow room for $30 \mathrm{~d}$. Nonplanted dummy pots were used to maintain a constant number of pots in each replication. Pots in the indoor grow room were watered as per experiment 1 . Four frozen pots were randomly selected to be removed from the freezer at 2, 4, 6, 8, or $16 \mathrm{~d}$ postfreezing and placed within blocks in the indoor grow room. Seedling density was counted daily, and after 30 days in the indoor grow area, pots were assessed for seedling density and number of tillers per seedling.

\section{Data Analysis}

Data were examined for skewness and kurtosis (PROC UNIVARIATE, SAS Institute 1999). When normality or homogeneity of variance assumptions were violated, data were weighted by the inverse of the treatment variance (Neter et al. 1990; James and Drenovsky 2007). We used mixed-model analysis of variance (SAS Institute 1999) to model 1) the 

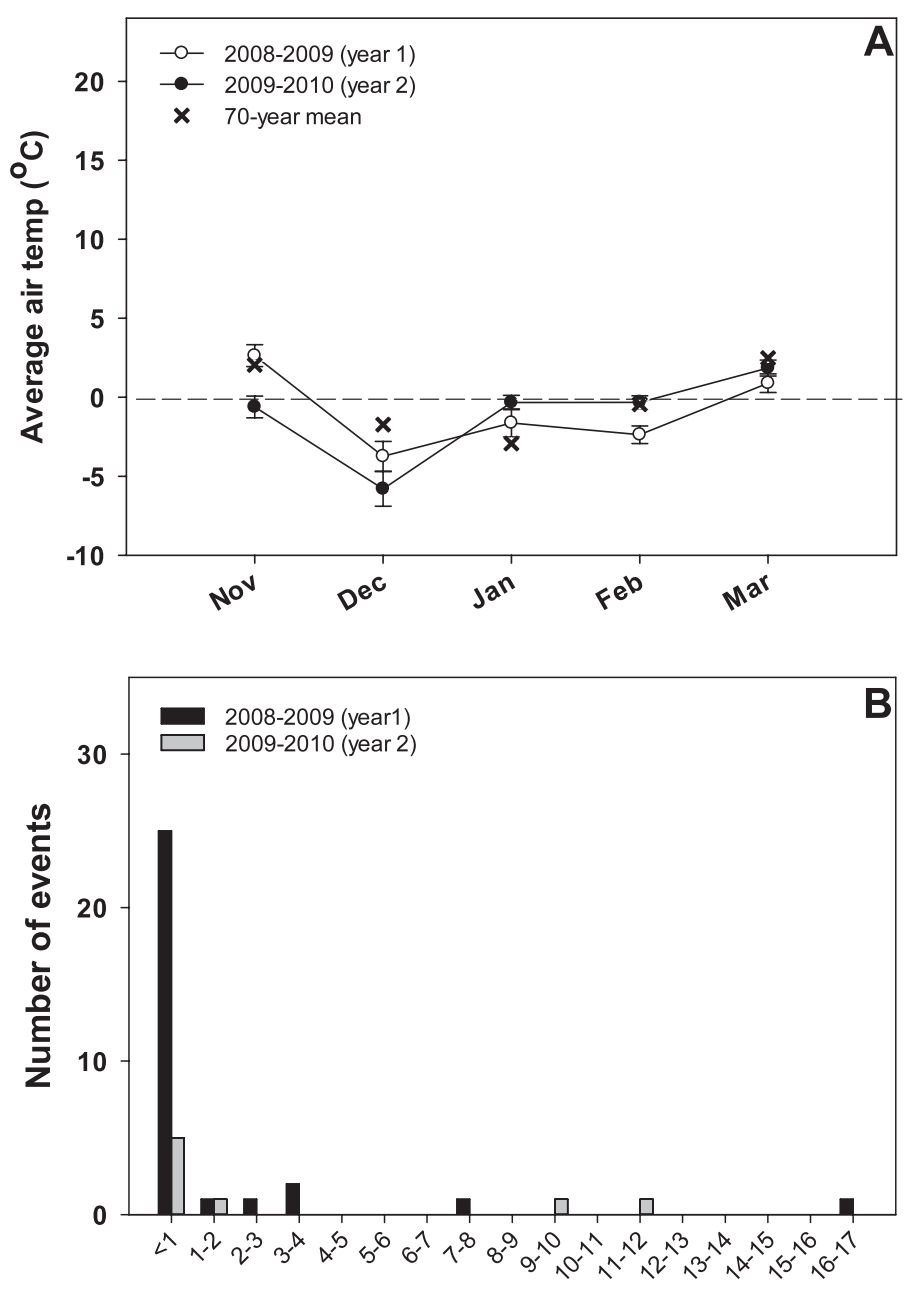

Freeze duration (days)

Figure 1. Monthly winter air temperature for the 2-yr pilot study as compared to long-term mean (1936-2006) (A); frequency and duration of winter (November-March) soil freezing events during the pilot study (B).

influence of freezing treatment and developmental class on seedling emergence and tiller production (experiment 1), and 2) the influence of freezing duration on seedling emergence and tiller production (experiment 2). For both models, covariance structure was determined with the use of the Akaike's Information Criterion (Littell et al. 1996). Block and the block $\times$ treatment interaction were considered random effects in both models. When significant main or interactive effects were found we assessed differences in treatment means with the use of the LS MEANS (SAS Institute 1999) procedure $(\alpha=0.05)$. All mean values are reported with their associated standard error.

\section{RESULTS}

Data from the pilot study indicate that average monthly air temperatures closely tracked long-term averages but were below normal in November of year 2 and February of year 1 (Fig. 1A). Average soil temperature for freezing periods $\geq 24 \mathrm{~h}$ was $-1.15^{\circ} \mathrm{C}$ and ranged from $-7.20^{\circ} \mathrm{C}$ to $-0.02^{\circ} \mathrm{C}$ in 2008 2009 (year 1). Average soil freezing temperature in 2009-2010

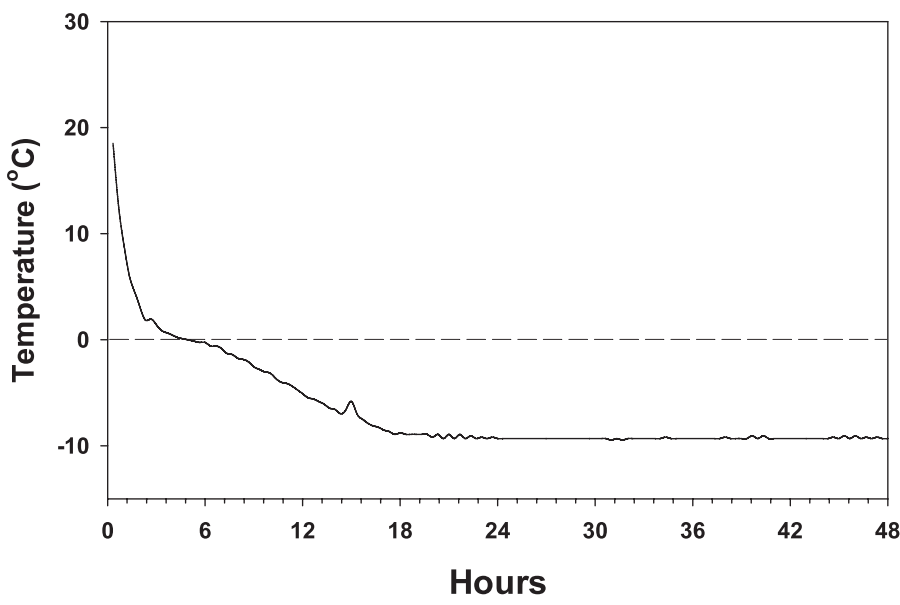

Figure 2. Rate of decline in temperature over time for soil in pots frozen at $-8.9^{\circ} \mathrm{C}$ in a laboratory freezer.

(year 2) was $-2.99^{\circ} \mathrm{C}$ and ranged from $-10.70^{\circ} \mathrm{C}$ to $-0.25^{\circ} \mathrm{C}$. Number of days where average soil temperature was below freezing was 51 in year 1 and 25 in year 2. Most periods of soil freezing were less than $1 \mathrm{~d}$ in duration (Fig. 1B). Maximum number of consecutive days for freezing soil conditions was 16.5 in year 1 and 11.2 days in year 2. Decline in temperature over time for frozen pots in experiments 1 and 2 is depicted in Figure 2. These data indicate that minimum soil temperature was reached within $24 \mathrm{~h}$ following entry into the freezer.

In experiment 1 , time to first seedling emergence was shortest for nonfrozen germinated treatments and ranged up to $9 \mathrm{~d}$ $( \pm 3.67)$ for the frozen $<2-\mathrm{mm}$ radicle class (Table 1$)$. The average last day of seedling emergence ranged from $4 \mathrm{~d}( \pm 0.71)$ for the $>2$-mm radicle class to $13.75 \mathrm{~d}( \pm 2.39)$ for the $<2$-mm radicle class (Table 1$)$. In experiment 2 , average first day of seedling emergence ranged from 1 day $( \pm 0)$ for the nonfrozen treatment to $7.33( \pm 1.2)$ for seedlings in the 8 -d freeze treatment. The average last day of seedling emergence ranged from $3.75 \mathrm{~d}( \pm 3.10)$ for the nonfrozen treatment to $10.33 \mathrm{~d}$ $( \pm 1.33)$ for the seedlings in the 8 -d freeze treatment (Table 1).

Seedling density in experiment 1 varied by freezing treatment $(P<0.001)$, developmental class $(P<0.001)$ and the interaction $(P<0.001)$. Seedling density values for nonfrozen seeds and seedlings ranged from 20 seedlings $\cdot$ pot $^{-1}( \pm 0)$ for the $<2$ $\mathrm{mm}$ radicle class to 18.25 seedlings pot $( \pm 0.85)$ for the nongerminated class but did not vary between classes (Fig. 3A). Seedling density values for frozen treatments ranged from 17.7 seedlings $\cdot \operatorname{pot}^{-1}( \pm 0.7)$ for the nongerminated class to 0 seedlings $\cdot$ pot $^{-1}$ for seeds germinated in situ and the coleoptile stage classes (Fig. 3A). Seedling density for frozen, nongerminated seeds did not differ from nonfrozen, nongerminated controls $(P>0.05)$; for all remaining classes, density of frozen treatments was less than for nonfrozen controls and density declined with advancing postgermination stage (Fig. 3A). The average number of tillers per seedling varied by freeze treatment $(P<0.001)$ developmental class $(P<0.001)$ and the interaction $(P<0.001)$. Tiller numbers for the nonfrozen treatment were numerically highest for the $>2-\mathrm{mm}$ radicle length class (3.37 tillers · seedling ${ }^{-1} \pm 0.15$ ) and decreased to a low of 2.06 tillers $\cdot$ seedling ${ }^{-1}( \pm 0.08)$ for seeds germinated in situ (Fig. 3B). For frozen treatments, tillers per seedling ranged 
Table 1. Day of first and last seedling emergence for pots planted with bluebunch wheatgrass seedlings. Pots were placed in an indoor grow room for 30 $\mathrm{d}$ either immediately after planting or following a prescribed freezing treatment.

\begin{tabular}{|c|c|c|c|c|c|c|}
\hline Experiment & Developmental class & Freezing treatment & Day of first emergence & SE & Day of last emergence & SE \\
\hline \multirow[t]{10}{*}{ Experiment 1} & \multirow[t]{2}{*}{ Nongerminated } & Frozen & 5.75 & 0.25 & 9.25 & 0.85 \\
\hline & & Nonfrozen & 5.00 & 0.00 & 7.00 & 0.00 \\
\hline & \multirow[t]{2}{*}{ Germinated in situ } & Frozen & - & - & - & - \\
\hline & & Nonfrozen & 1.00 & 0.00 & 4.00 & 0.71 \\
\hline & \multirow[t]{2}{*}{$<2$-mm radicle } & Frozen & 9.00 & 3.67 & 13.75 & 2.39 \\
\hline & & Nonfrozen & 2.50 & 0.29 & 4.25 & 0.63 \\
\hline & \multirow[t]{2}{*}{$>2$-mm radicle and no coleoptile } & Frozen & 5.00 & - & 5.00 & - \\
\hline & & Nonfrozen & 1.00 & 0.00 & 4.00 & 0.00 \\
\hline & \multirow[t]{2}{*}{ Coleoptile present } & Frozen & - & - & - & - \\
\hline & & Nonfrozen & 1.00 & 0.00 & 7.00 & 2.04 \\
\hline \multirow[t]{5}{*}{ Experiment 2} & - & Nonfrozen & 1.00 & 0.00 & 3.75 & 3.10 \\
\hline & - & 2-d freeze & 2.50 & 0.29 & 9.00 & 2.94 \\
\hline & - & 4-d freeze & 4.50 & 1.50 & 5.50 & 0.50 \\
\hline & - & 8-d freeze & 7.33 & 1.20 & 10.30 & 1.30 \\
\hline & - & 16-d freeze & 4.67 & 0.67 & 9.67 & 4.26 \\
\hline
\end{tabular}

from 2.77 tillers $\cdot$ seedling ${ }^{-1}( \pm 0.09)$ for the nongerminated class to a low of 0.25 tillers $\cdot$ seedling ${ }^{-1}( \pm 0.25)$ for the $>2-\mathrm{mm}$ radicle and no coleoptile class (Fig. 3B). Our data suggest that tillers per seedling decreased with advancing postgermination stage at time of planting, and with the exception of nongerminated seeds, frozen treatments consistently had lower tillers per seedling than nonfrozen treatments. For seeds that were germinated in situ, our data indicate that $55 \%$ of planted seeds had germinated by $5 \mathrm{~d}$ postplanting and that $90 \%$ of the germinated seeds had progressed to $>2-\mathrm{mm}$ radicle length.

Seedling density in experiment 2 varied by freezing duration $(P<0.001)$ and ranged from 19.5 seedlings $\cdot$ pot $^{-1}( \pm 0.05)$ for nonfrozen to a low of 1.0 seedlings $\cdot \operatorname{pot}^{-1}( \pm 0.71)$ for pots frozen for 4 days (Fig. 4A). The effect of freezing duration on density of seedlings was binomial in nature; all freezing durations had lower density (at least a fourfold reduction) than nonfrozen controls and there was no clear pattern of change in seedling density with increasing duration of freezing (Fig. 4A). Tiller production was influenced by freezing duration $(P=0.001)$ and was highest for nonfrozen pots (3.36 tillers $\cdot$ seedling $\left.{ }^{-1} \pm 0.14\right)$ and decreased with freezing for longer than $4 \mathrm{~d}$ (Fig. 4B). With the exception of the 2- and 4-d freeze treatments, all freezing durations yielded fewer tillers/seedlings (compared to nonfrozen), but there was not a clear relationship between increasing freeze duration and decreasing number of tillers/seedling (Fig. 4B).

\section{DISCUSSION}

Low emergence rates for planted perennial grass seed have severely limited restoration effectiveness in low- to midelevation sagebrush plant communities in the western United States (James and Svejcar 2010; Davies et al. 2011; James et al. 2011). These low success rates have increased the need for a better understanding of factors influencing the mortality of germinated perennial grass seeds. Consistent with our initial hypothesis, we found that emergence of germinated seedlings was dramatically reduced under frozen soil conditions. Previous research indicates that germination of fall-planted perennial grass seeds in the Intermountain West largely occurs prior to winter onset, and that emergence of germinated seeds in the following spring is the most limiting demographic stage for seeded perennial grasses in the sagebrush steppe (McLean and Wikeem 1983; James and Svejcar 2010; Boyd and James in press). Various authors have speculated that germinated seeds exposed to winter soil conditions can suffer high mortality (e.g., Reicher et al. 2000; James et al. 2011) but little empirical evidence is available to test this hypothesis. Our data indicate that exposure of germinated seeds to freezing conditions could be an important source of pre-emergent mortality and suggest that timing of germination, relative to onset of frozen soil conditions, could be a critical determinant of emergence.

We found support for the hypothesis that developmental status at the time of soil freezing can modulate the degree of freeze-related reduction in emergence. As predicted, seedling emergence for seeds in early postgermination was higher than for more advanced stages (Fig. 3). Contemporary data for bluebunch wheatgrass was not found in the literature. However, Arakeri and Schmid (1949) reported that freeze survival of timothy (Phleum pretense L.), reed canary grass (Phalaris arundinacea L.), Kentucky bluegrass (Poa pratensis L.), and meadow fescue (Schedonorus pratensis [Huds.] P.Beauv.) increased nearly $50 \%$ as seedlings progressed from late postgermination stages (coleoptile present) to early emergence. Developmental stage-dependent freezing tolerance has also been reported in woody plants. In contrast to our results, Coursolle et al. (1998) noted that frost tolerance of germinated white spruce (Picea glauca [Moench] Voss) seeds increased with advancing seedling development, but only within certain developmental bounds. These authors reported decreased risk of freeze mortality for seedlings at the cotyledon to early-emergent stages, as compared to seedlings in early radicle development. In this study freezing had minimal effect on germinated (water imbibed) seeds prior to early radicle development.

Our data also support the hypothesis that freezing effects on density of emergent seedlings can occur within a relatively 


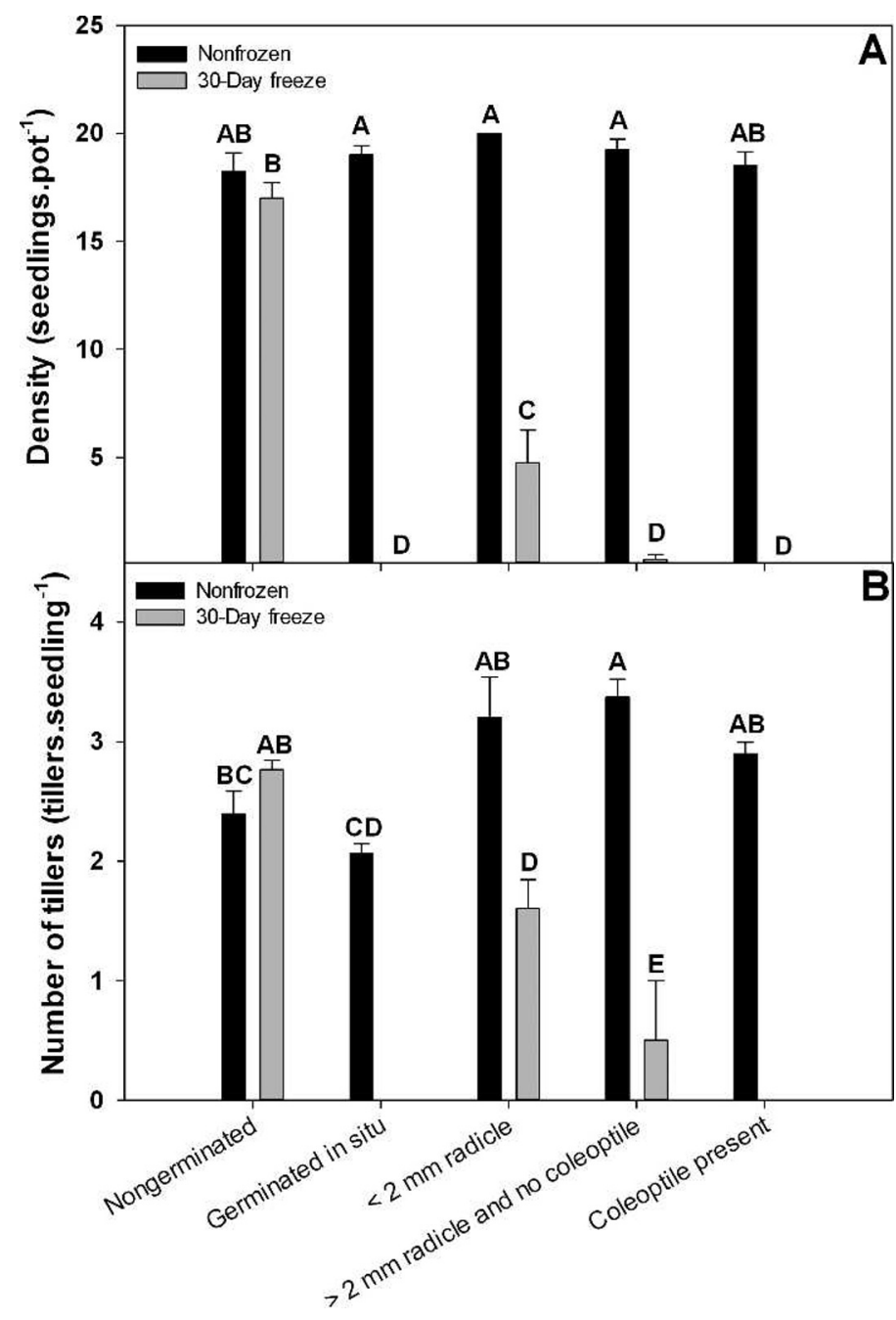

Figure 3. Effects of freezing treatment and developmental status on (A) density, (B) number of tillers for bluebunch wheatgrass seedlings. Nonfrozen pots were placed in a grow-room environment after being planted with 20 seeds at specific germination stages. Frozen pots were placed in a freezer $\left(-7.5^{\circ} \mathrm{C}\right)$ for $30 \mathrm{~d}$ following planting and then moved to an indoor grow room for $30 \mathrm{~d}$. Seeds germinated in situ were planted in pots $5 \mathrm{~d}$ prior to being placed in the grow room or freezer. Nongerminated seeds were not germinated at time of planting and remaining treatments indicate postgermination stage at time of planting.

short period of time following onset of frozen soils; results suggest that maximum reduction in seedling emergence occurs within 2-4 d of onset of freezing soil conditions (Fig. 4A). Additionally, data from the pilot study indicate that freezing conditions of 2-4-d durations occurred multiple times over two winter periods (Fig. 1B). Given that air temperatures during this same time period did not severely depart from long-term averages (Fig. 1A), it seems reasonable to expect that multiple soil freezing periods of sufficient duration to impact seedling emergence would occur under average overwinter temperature conditions. Our freezing regime in experiment 1 differed from data recorded in the pilot study in that we did not use multiple freeze-thaw cycles typical of field conditions. Instead, we froze seeds for a continuous period of $30 \mathrm{~d}$, which was within the range of total freezing days per year recorded in the pilot study. Our decision to use a continuous freeze period was based on

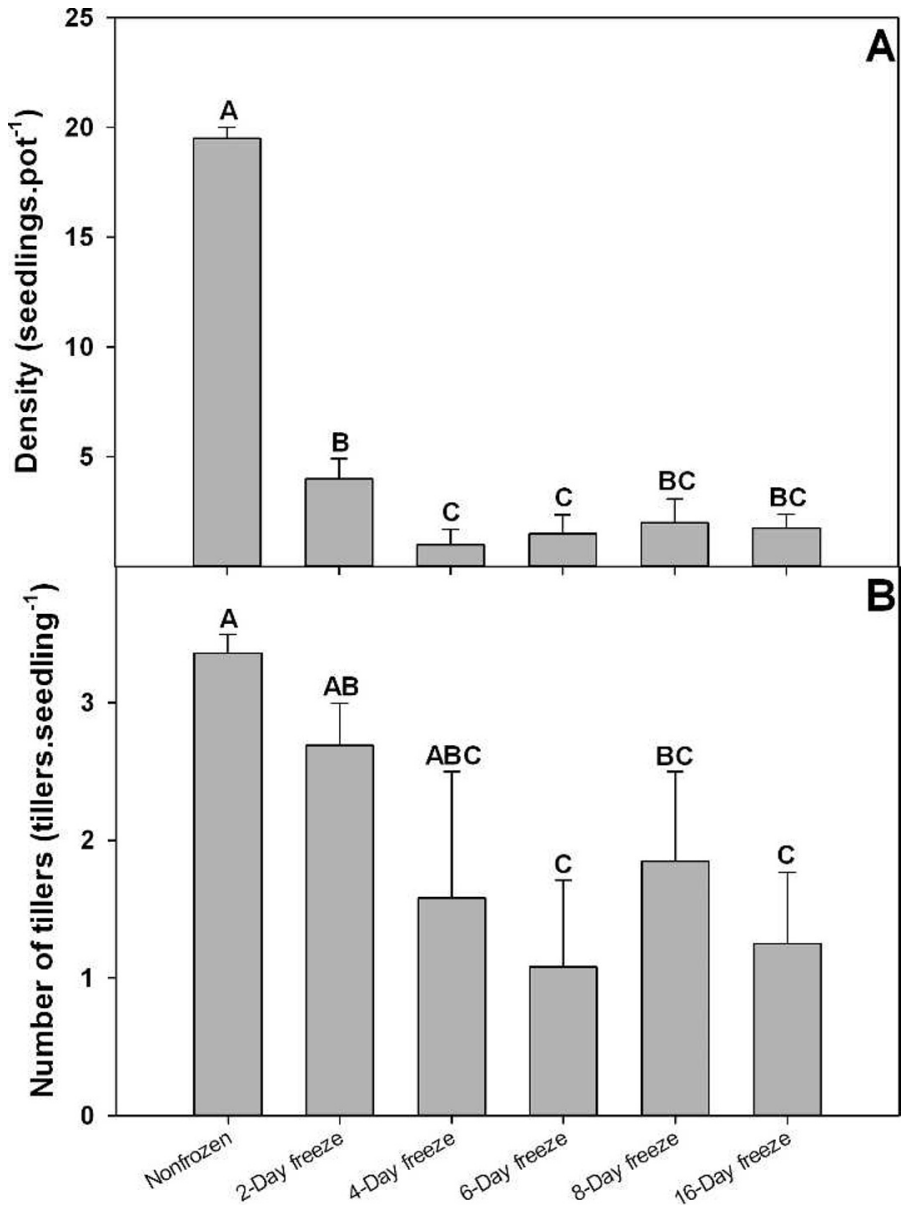

Figure 4. Effects of freezing treatment and developmental status on (A) density, (B) number of tillers for bluebunch wheatgrass seedlings. Nonfrozen pots were placed in an indoor grow room environment after being planted with 20 seeds and frozen pots were placed in a freezer following planting and then moved to the grow room for $30 \mathrm{~d}$. All seeds were postgermination (radicle $\geq 2 \mathrm{~mm}$ ) at the time of planting.

the logistical challenges of simulating variable temperature conditions with our laboratory equipment. We suspect that freezing effects imparted by our continuous freeze period were probably conservative relative to the physical stresses of multiple freeze-thaw cycles. The fact that increasing freeze duration in experiment 2 did not clearly correlate with reductions in seedling density (Fig. 4A) is at minimum consistent with the idea that freezing duration may be less important than seed damage from the mechanical stresses of freezing and thawing.

A potential mechanism for decreased seedling density with freezing treatment (Figs. 3A and 4A) is that freezing delayed emergence and our experimental protocol did not allow sufficient time for seedlings in frozen treatments to emerge. However, our observations at time of harvest, after $30 \mathrm{~d}$ in the indoor grow room, indicate that nonemergent seedlings were in varying stages of decomposition and would not have emerged given additional time in the grow facility. Also, the average day of last emergence for frozen treatments was more than 2 wk prior to the end of the 30-day grow period, further suggesting that additional time would not have produced higher emergence. 
In addition to soil freezing effects on seedling density, postgermination freezing also reduced vigor of emergent seedlings with respect to the number of tillers per seedling. These effects mirrored those noted above for seedling density; tiller numbers decreased with postgermination planting (Fig. 3B) and with freezing beyond $4 \mathrm{~d}$ (Fig. 4B). Similarly, Bai et al. (1998) reported reduced seedling vigor for freeze-stressed winterfat (Eurotia lanata [Pursh] Moq.) seeds. However, tiller production in our study was somewhat confounded with day of emergence, because nonfrozen treatments tended to emerge earlier than frozen. Additionally, seedlings frozen in late postgermination (experiment 1) tended to emerge earlier than those frozen in early postgermination, making it difficult to definitively partition the effects of freezing vs. seedling age on tillers/seedling. That said, delayed tiller production itself could be of ecological significance if it reduces the ability of a seedling to capitalize on seasonal windows of resource availability (James and Richards 2006).

One of the potential difficulties in experimentally manipulating germinated grass seeds is that handling these seeds could damage either the radicle or coleoptile, resulting in impaired seedling emergence. Our data indicate that seed handling did not impair seedling performance in this study. Specifically, in experiment 1 emergence values for nonfrozen seeds planted prior to germination were not higher than for nonfrozen seedlings planted at various stages of postgermination. In fact, seedlings planted with $<2$-mm radicle had numerically higher emergence than the nongerminated treatment (Fig. 3A). Additionally, the fact that freezing tolerance of seeds germinated in situ was similar to that of most lab-germinated treatments (e.g., Fig. 3) suggests that our results may be applicable to field-germination scenarios. One factor not addressed by our experimental design that could potentially effect resistance of germinated seeds to freezing stress is the issue of cold hardening (i.e., thermal acclimation, Lagerspetz 2006). Previous work suggests that exposure of seedlings to low but nonfreezing temperatures can increase survival upon subsequent exposure to freezing conditions. Others have found that cold-hardening capacity is strongly tied to postgermination developmental stage and that freezing tolerance is not increased until postcoleoptile/cotyledon development (Arakeri and Schmid 1949; Coursolle et al. 1998; Hawkins et al. 2003). This work suggests that the precoleoptile-emergence developmental stages incorporated in the present study would not realize increased emergence performance with cold hardening treatment.

\section{MANAGEMENT IMPLICATIONS}

In the western United States, perennial bunchgrasses are typically seeded during the fall and a large proportion of planted seeds can germinate prior to winter onset; success of these seedlings is often very low. Our data suggest that frozen soil conditions during winter may substantially reduce eventual emergence as well as postemergence vigor of germinated perennial bunchgrass seeds and that the severity of this effect is associated with postgermination developmental stage, and to a lesser extent, duration of freezing. From a management standpoint, these data imply that timing of germination may be critical to emergence and establishment of fall-planted bluebunch wheatgrass. Altering timing of planting to a later calendar date could reduce the amount of germination prior to frozen soil conditions in winter (Boyd and James in press) and subsequent freeze-related mortality of germinated seeds. Alternatively, it may be possible to use seed coatings (e.g., hydrophobic coatings, Scott 1989) to delay germination until spring when potential for frozen soil conditions is reduced. Additional research is needed to explore the potential for using cold-hardening treatments to increase the freezing tolerance of developing bluebunch wheatgrass seedlings.

\section{ACKNOWLEDGMENTS}

The authors wish to thank Dr Matt Madsen and Dr Stuart Hardegree for thoughtful review of an earlier draft of this manuscript. Thanks also to Katie Seasa for her efforts with data collection.

\section{LITERATURE CITED}

Arakerl, H. R., and A. R. Schmid. 1949. Cold resistance of various legumes and grasses in early stages of growth. Agronomy Journal 41:182-185.

Bal, Y., D. T. Bоoth, And J. T. Romo. 1998. Winterfat (Eurotia lanata (Pursh) Moq.) seedbed ecology: low temperature exotherms and cold hardiness in hydrated seeds as influenced by imbibitions temperature. Annals of Botany 81:595-602.

BOYD, C. S., AND J. J. James. Variation in timing of planting influences bluebunch wheatgrass demography in an arid system. Rangeland Ecology \& Management 66:117-126.

Boyd, C. S., AND T. J. SveJCAR. 2009. Managing complex problems in rangeland ecosystems. Rangeland Ecology \& Management 62:491-499.

Chambers, J. C., B. A. Roundy, R. R. Blank, S. E. Meyer, and A. Whittaker. 2007. What makes Great Basin sagebrush ecosystems invasible by Bromus tectorum? Ecological Monographs 77:117-145.

Coursolle, C., F. J. Bigras, and H. A. Margolis. 1998. Frost tolerance and hardening capacity during the germination and early developmental stages of four white spruce (Picea glauca) provenances. Canadian Journal of Botany 76:122-129.

Crawford, J. A., R. A. Olson, N. E. West, J. C. Mosley, M. A. Schroeder, T. D. Whitson, R. F. Mlller, M. A. GregG, AND C. S. Boyd. 2004. Ecology and management of sage-grouse and sage-grouse habitat. Journal of Range Management 57:2-19.

D'Antonio, C. M., And P. M. Vitousek. 1992. Biological invasions by exotic grasses, the grass/fire cycle, and global change. Annual Review of Ecology and Systematics 23:63-87.

Davies, K. W., C. S. Boyd, J. L. Beck, J. D. Bates, T. J. Svejcar, and M. A. Gregg. 2011. Saving the sagebrush sea: an ecosystem conservation plan for big sagebrush plant communities. Biological Conservation 144:2573-2584.

Hardegree, S. P., T. A. Jones, B. A. Roundy, N. L. Shaw, and T. A. Monaco. 2011. Assessment of range planting as a conservation practice. In: D. D. Briske [ED.]. Conservation benefits of rangeland practices: assessment, recommendations, and knowledge gaps. Washington, DC, USA: USDA-NRCS. p. 171-212.

Hawkins, B. J., H. J. GUEST, AND D. KoLotelo. 2003. Freezing tolerance of conifer seeds and germinants. Tree Physiology 23:1237-1246.

HuLl, A. C. 1974. Species for seeding arid rangeland in southern Idaho. Journal of Range Management 27:216-218.

James, J. J., AND R. E. DRenovsky. 2007. A basis for relative growth rate differences between native and invasive forb seedlings. Rangeland Ecology \& Management 60:395-400.

JAMES, J. J., AND J. H. RiCHARDS. 2006. Plant nitrogen capture in pulse-driven systems: interactions between root responses and soil processes. Journal of Ecology 94:765-777.

James, J. J., AND T. J. SveJCAR. 2010. Limitations to postfire seedling establishment: the role of seeding technology, water availability, and invasive plant abundance. Rangeland Ecology \& Management 63:491-495. 
James, J. J., T. J. Svejcar, and M. J. Rinella. 2011. Demographic processes limiting seedling recruitment in arid grassland restoration. Journal of Applied Ecology 48:961-969.

LAGERSPETZ, K. Y. H. 2006. What is thermal acclimation? Journal of Thermal Biology 31:332-336.

LAUDE, H. M. 1956. The seedling emergence of grasses as affected by low temperature. Agronomy Journal 48:558-560.

Littell, R. C., G. A. Milliken, W. W. Stroup, and R. D. Wolfinger. 1996. SAS system for mixed models. Cary, NC, USA: SAS Institute.

Lysne, C. R., AND M. Pellant. 2004. Establishment of aerially seeded big sagebrush following southern Idaho wildfires. Boise, ID, USA: US Department of the InteriorBureau of Land Management. Technical Bulletin 2004-01. 14 p.

McLean, A., AND S. J. WIKEEM. 1983. Effect of time of seeding on emergence and longterm survival of crested wheatgrass in British Columbia. Journal of Range Management 36:694-700.

Mosley, J. C., S. C. Bunting, and M. E. Manoukian. 1999. Cheatgrass. In: R. L. Sheley and J. K. Petroff [EDS.]. Biology and management of noxious rangeland weeds. Corvallis, OR, USA: Oregon State University Press. p. 175-188.
Neter, J., W. Wasserman, and M. H. Kutner. 1990. Applied linear statistical models: regression, analysis of variance and experimental design. 3rd ed. Homewood, IL, USA: Irwin. 1408 p.

Richards, R. T., J. C. Chambers, and C. Ross. 1998. Use of native plants on federal lands: policy and practice. Journal of Range Management 51:625-632.

Reicher, Z. J., C. S. Throssell, and D. V. Weisenberger. 2000. Date of seeding affects establishment of cool-season turfgrasses. HortScience 35:1166-1169.

SAS InStITUTE Inc. 1999. SAS procedures guide, release 8.0. Cary, NC, USA: SAS Institute. $1624 \mathrm{p}$.

ScotT, J. M. 1989. Seed coatings and treatments and their effects on plant establishment. Advances in Agronomy 42:43-83.

Whisenant, S. G. 1990. Changing fire frequencies in Idaho's Snake River Plains: ecological and management implications. In: E. D. McArthur, E. M. Romney, S. D. Smith, and P. T. Tueller [EDS.]. Symposium on Cheatgrass Invasion, Shrub DieOff, and Other Aspects of Shrub Biology and Management; 5-7 April 1990; Las Vegas, NV, USA. Ogden, UT, USA: USDA Forest Service. p. 4-10. 